\title{
Properties of Empty Fruit Bunches Eco-Composite Boards from Elaeis guineesis
}

\author{
Razak Wahab (Corresponding author) \\ University College of Technology Sarawak, \\ 96000 Sibu, Sarawak, Malaysia
}

Email: drrazakw5181@ucts.edu.my

Mohd Tamizi Mustafa

Forest Research Institute Malaysia (FRIM), 52109 Kuala Lumpur, Malaysia

\author{
Mohd Sukhairi Mat Rasat \\ Universiti Malaysia Kelantan (UMK), Jeli Campus, \\ 17600 Jeli, Kelantan, Malaysia \\ Siti Marlia Mohd Don \\ Universiti Malaysia Kelantan (UMK), Jeli Campus, \\ 17600 Jeli, Kelantan, Malaysia
}

Received: May 31, 2017

doi:10.5296/jas.v5i3.11300
Accepted: June 19, 2017 Published: July 20, 2017

URL: https://doi.org/10.5296/jas.v5i3.11300

\begin{abstract}
This studies investigated on the properties of eco-composite boards made from Elaeis guineesis empty fruit bunch. The empty fruit bunches (EFB) collected from a private Elaeis guineesis plantation in Selangor. The EFB refined using fiber cutter and particle crusher. Hardeners and wax added at $1 \%$ and $3 \%$ during the mixing process. Boards with densities of 700,600 and $500 \mathrm{~kg} / \mathrm{m}^{3}$ produced using resin urea formaldehyde as the bonding agent at 10 , 12 and $14 \%$. The boards conditioned in a conditioning chamber set at $20 \pm 2^{\circ} \mathrm{C}$ and $65 \%$
\end{abstract}


relative humidity before undergoing subsequent testing. Preparation for boards and tests samples follows BS and EN Standards specifications. Maximum modulus of rupture (MOR) were $22.91 \mathrm{~N} / \mathrm{mm}^{2}$ and modulus of elasticity (MOE) $2059.56 \mathrm{~N} / \mathrm{mm}^{2}$. The internal bonding recorded at $0.98 \mathrm{~N} / \mathrm{mm}^{2}$, for the edge and face screw withdrawal were at $467.47 \mathrm{~N} / \mathrm{mm}^{2}$ and $512.37 \mathrm{~N} / \mathrm{mm}^{2}$ respectively. The boards with $700 \mathrm{~kg} / \mathrm{m}^{3}$ density and $14 \%$ resin content met the required standard with good dimensional stability. In the thermogravimetric analysis the maximum rate of decomposition for the EFB boards occurred at $380.83^{\circ} \mathrm{C}$. The board's overall properties are influence by the density and resin content applied.

Keywords: Elaeis guineesis, empty fruit bunches, eco-composite boards, physical and strength properties, thermogravimetric analysis.

\section{Introduction}

Wood composites products have nowaday become popular in the timber industry due to the scarcity in obtaining natural timber. The demands for these commodities increases due to the shortage of the wood supply (Wahab et al., 2016a; 2008; Rasat et al., 2013a). Elaeis guineesis or oil palm is a valuable plantation in Malaysia. The E. guineesis become economically unproductive after 25-30 years and need to be replanting. Huge amount of oil palm biomass becomes available during this period. This biomass is normally left in the fields to rot. This readily resource could be used as a raw material for wood-based industry (Rasat et al., 2013b; 2013c; 2013d). Studies has been initiated to find suitable uses of this lignocellulose material from E. guineesis trunks as an alternative to replace wood in wood-based panel industry. The empty fruit bunches (EFB) is a lignocellulosic material that has potential as the natural fiber resource. EFB are available in abundance in Malaysia, converting them into composite boards can reduced pressure on wood sources in the tropical region of the world. EFB amounting to 12.4 million tons per year (fresh weight) and regularly discharged from palm oil refineries (Khalil et al., 2007). EFB is a poor material fuel and presents a considerable emission problem during burning. E. guineesis mills typically use the shell and drier part of the fiber product rather than EFB, to fuel their boilers (Abdullah \& Bridgwater, 2006).

This study focused on the physical, mechanical properties, microscopy studies using Scanning Electron Microscope (SEM) on resin-fiber bonding properties and thermal properties of the boards. The information obtained in the study can help the wood industry in enhancing the utilization of the oil palm biomass.

\section{Materials and Methods}

The EFB were collected from an Elaeis guineesis plantation located in Kuala Selangor, Selangor. The materials were refined into smaller size using the mechanical cutter and crusher. A four-tier sieve shaker used to screen and remove the oversize, fines and impurities. The particles that passed through $2.0 \mathrm{~mm}$ sieve size and retained at $1.5 \mathrm{~mm}$ sieve size. The particles oven-dried at $103 \pm 2{ }^{\circ} \mathrm{C}$ for $24 \mathrm{hrs}$. The mass of the particles was measured to obtain targeted densities of 700,600 and $500 \mathrm{~kg} / \mathrm{m}^{3}$. They mixed with the urea-formaldehyde (UF) resin in a mixing drum. Three (3) levels of resin content applied to the boards' production at 
10, 12 and 14\%. The mixed particles hand-felted into a wooden frame $340 \times 340 \mathrm{~mm}$ size of a caul plate. The formed mat was pre-pressed by using the cold press machine. The forming frame removed leaving the mat on the caul plate. The mat hot-pressed under Taihei hot-press machine at temperature $165^{\circ} \mathrm{C}$ to the duration of 6 minutes. Four metal bars of $12 \mathrm{~mm}$ thickness used in the hot-pressing process. The boards produced were then cooled and cut into standard testing size. The testing samples stored in a conditioning chamber conditioned at $20 \pm 2^{\circ} \mathrm{C}$ and $65 \%$ relative humidity until reaching their constant weight, before the testing procedure. Boards at densities of 700,600 and $500 \mathrm{~kg} / \mathrm{m}^{3}$ and UF resin applied at 10, 12 and $14 \%$ produced in laboratory scale. All boards provided by European standards (EN standards).

\subsection{Physical Properties}

The studies conducted were the density, moisture content, water absorption, and thickness swelling tests of 2 and 24 hours elapsed of the EFB composite boards. The physical studies carried out in accordance to the EN 322 (European standard, 1993a), EN 323 (European standard, 1993b) and EN 317 (European standard, 1993c).

\subsection{Mechanical Properties}

The studies carried out including the static bending for modulus of rupture (MOR) and modulus of elasticity (MOE), internal bonding test and the screw withdrawal test (edge and face). All tests conducted using the universal testing machine in according to the standard of EN 310 (European standard, 1993d) and EN 325 (European standard, 2012).

Screw hold strength of the composite boards tested according to the standard of BS 5669 (British standard, 1989). The edge screw withdrawal test conducted to evaluate the screw holding strength at the edge sections of the boards. A screw inserted upright into the holes at the edge side of the test sample and placed in a stirrup attached to the load. The edge screw withdrawal property obtained as the load applied to a pulling action.

\subsection{Thermogravimetric Analysis}

Thermogravimetric analysis (TGA) used to measure the thermal stability of the boards. The weight changed with temperature measured and used to infer the moments of change during the heating. Temperature occurred when the boards started to degrade are taken as an indicator of the stability of the material (Soom et al., 2006). TGA was carried out with a digital TA Instrument SDT-Q600 thermogravimetric analyzer. Samples $(5.5 \pm 0.2 \mathrm{mg})$ placed in alumina crucibles. TGA performed under $100 \mathrm{mlmin}^{-1}$ nitrogen with a heating rate of $10^{\circ} \mathrm{C}$ $\min ^{-1}$.

\section{Results and Discussion}

\subsection{Physical Properties}

Table 1 shows the density and thickness swelling of the EFB composite boards. Boards' at density $500 \mathrm{~kg} / \mathrm{m}^{3}$ with $10 \%$ resin content level had an average density of $506.29 \mathrm{k} / \mathrm{gm}^{3}, 12 \%$ resin content with $506.9 \mathrm{~kg} / \mathrm{m}^{3}$ and $14 \%$ resin content at $517.6 \mathrm{~kg} / \mathrm{m}^{3}$. Board $600 \mathrm{~kg} / \mathrm{m}^{3}$ with 
$10 \%$ resin content level had an average density of $598.65 \mathrm{~kg} / \mathrm{m}^{3}, 12 \%$ resin content with $608.9 \mathrm{~kg} / \mathrm{m}^{3}$ and $14 \%$ resin content at $620.05 \mathrm{k} / \mathrm{gm}^{3}$. Average density of the board $700 \mathrm{~kg} / \mathrm{m}^{3}$ is $704.03 \mathrm{~kg} / \mathrm{m}^{3}$ with $10 \%$ resin, $714.72 \mathrm{kgm}^{-3}$ with $12 \%$ resin, and $723.89 \mathrm{k} / \mathrm{gm}^{3}$ with $14 \%$ resin. The boards at density $500 \mathrm{~kg} / \mathrm{m}^{3}$ possess MC value of $6.89 \%$ at $10 \%$ resin, $7.15 \%$ at $12 \%$ resin, and $8.48 \%$ at $14 \%$ resin. Boards at $600 \mathrm{~kg} / \mathrm{m}^{3}$ has $\mathrm{MC}$ of $6.04 \%$ at $10 \%$ resin, $6.83 \%$ at $12 \%$ resin, and $6.48 \%$ at $14 \%$ resin. The board's density of 700 possesses MC at $6.64 \%$ with $10 \%$ resin, $6.72 \%$ with $12 \%$ resin, and $7.12 \%$ with $14 \%$ resin.

The thickness swelling properties of the EFB composite boards manufactured obtained from the thickness swelling analysis. Time elapsed of 2 and 24 hours thickness swelling analysis was carried out, and percentage of increment of thickness then calculated. Boards with densities of 700,600 and $500 \mathrm{~kg} / \mathrm{m}^{3}$ possess a particular trend of 2 and 24 hours thickness swelling where the swelling decreases as the amount of resin applied increases. The boards at $500 \mathrm{~kg} / \mathrm{m}^{3}$ at resin content $10 \%$ had the highest rate of thickness swelling for 2 hours' time elapsed at $35.1 \%$. The lowest value of 2 hours thickness swelling given by the board 700 $\mathrm{kg} / \mathrm{m}^{3}$ with resin content $14 \%$ at $16.34 \%$. The highest value for 24 hours, thickness swelling was attained by the board $500 \mathrm{~kg} / \mathrm{m}^{3}$ with resin content $10 \%$ at $41.11 \%$. The boards at 700 $\mathrm{kg} / \mathrm{m}^{3}$ with resin content $14 \%$ had the lowest 24 hours thickness swelling at $12.99 \%$.

Table 1: Density of EFB composite boards and values for thickness swelling at different density, resin contents for 2 and 24 hours time elapsed.

\begin{tabular}{cccccc}
\hline \multirow{2}{*}{$\begin{array}{c}\text { Board density } \\
\left(\mathrm{kg} / \mathrm{m}^{3}\right)\end{array}$} & $\begin{array}{c}\text { Resin content } \\
(\%)\end{array}$ & $\begin{array}{c}\text { Moisture } \\
\text { content }(\%)\end{array}$ & Density $\left(\mathrm{kg} / \mathrm{m}^{3}\right)$ & \multicolumn{2}{c}{ Thickness swelling (\%) } \\
\cline { 5 - 6 } 700 & 10 & $6.64(0.29)$ & $704.03(31.91)$ & $19.18(0.43)$ & $21.37(0.54)$ \\
& 12 & $6.72(0.46)$ & $714.72(7.21)$ & $17.46(1.20)$ & $16.88(0.43)$ \\
& 14 & $7.12(0.30)$ & $723.89(17.47)$ & $16.34(0.19)$ & $12.99(2.50)$ \\
\hline \multirow{2}{*}{600} & 10 & $6.04(0.72)$ & $598.65(14.43)$ & $24.04(2.56)$ & $25.46(1.50)$ \\
& 12 & $6.83(0.81)$ & $608.90(27.31)$ & $23.01(0.68)$ & $24.41(1.84)$ \\
& 14 & $6.48(1.16)$ & $620.05(25.19)$ & $20.90(1.73)$ & $21.41(2.78)$ \\
\hline \multirow{2}{*}{500} & 10 & $6.89(0.42)$ & $506.29(31.27)$ & $35.10(2.75)$ & $41.11(2.86)$ \\
& 12 & $7.15(0.43)$ & $506.90(25.54)$ & $26.44(3.42)$ & $38.25(2.61)$ \\
& 14 & $8.48(0.26)$ & $517.60(14.25)$ & $24.90(0.63)$ & $26.69(1.18)$ \\
\hline
\end{tabular}

Standard deviations shown in bracket.

Some chemical components in the resin applied capable of cross-linking with the hydroxyl group of the fiber reducing the hygroscopicity of the boards. Hygroscopic expansion can be affected by various factors of the resin, polymerization rates, cross-linking, and pore-size of the polymer network, bond strength, interaction between polymer and water, the filler and the resin-filler interface (Wong et al., 1999). According to the theory of voids over the volume of the board, the greater existence of the void that can mostly found in low-density boards than high-density boards may provide spaces that increase water absorption (Loh et al., 2010). In the low-density board, the highly porous structure allows penetration of water into the board and increases the water uptake resulting in high water absorption, causes the board to swell and gives rise in thickness swelling (Wong et al., 1999). 


\section{Mll Macrothink}

Journal of Agricultural Studies

ISSN 2166-0379

2017, Vol. 5, No. 3

Water absorption property of the EFB composite boards manufactured obtained from water absorption analysis. Time elapsed of 2 and 24 hours water absorption studies tested. The water absorption of EFB composite boards at different density, and resin content was shown in Table 2. Boards of 700, 600 and $500 \mathrm{~kg} / \mathrm{m}^{3}$ densities showed the same trend of 2 and 24-hour water abortion where the rate of the board absorbed water decreases as the amount of resin applied increases. Boards at density $500 \mathrm{~kg} / \mathrm{m}^{3}$ with resin content $10 \%$ had the highest rate of 2-hour water absorption at $139.02 \%$ while the lowest at $40.71 \%$ given by the 700 $\mathrm{kg} / \mathrm{m}^{3}$ board density of resin content $14 \%$. The highest rate of 24 hours water absorption attained by the board at $500 \mathrm{~kg} / \mathrm{m}^{3}$ density with resin content $10 \%$ at $206.77 \%$. The lowest value at 24 hours water intake at $59.62 \%$ obtained by the board $700 \mathrm{~kg} / \mathrm{m}^{3}$ with $14 \%$ resin. The increase in the board density resulted in a better thickness swelling performance and decreased water absorption of the boards (Wahab et al. 2016c; Rasat et al. 2013e; Guler \& Büyüksarı, 2011). The boards with high density absorbed more water than those with low density. The adhesion strength of the board decreases when the dwell inside the water increases, resulting in the increase in the thickness of the boards. The increment in the adhesion ratio resulted in low thickness swelling and water absorption for the boards. The swelled boards remained deficient even after the increases in the boards' density and adhesive (Wahab et al., 2016a; Garay et al., 2009). Increases in the density of the boards significantly improved the strength and water resistance (Zheng et al., 2005). The high-density boards possess large contact surface area between particles, making the adhesive function more efficiently compared to the lower density particle board (Zheng et al., 2005). The boards with higher density have less void volume, resulting in better water resistance. Although boards with high density normally correspond to high quality, it also means higher cost and weight of the finished composite board. Khalid et al. (2015) made a similar observation in their studies in the evaluation of layering effects and adhesive rates on laminated compressed composite panels from oil palm.

Table 2: Water absorption of EFB boards at different density and resin contents for 2 and 24 hours time elapsed.

\begin{tabular}{|c|c|c|c|c|c|}
\hline \multirow[b]{2}{*}{ Board density $\left(\mathrm{kg} / \mathrm{m}^{3}\right)$} & \multirow[b]{2}{*}{ Resin content (\%) } & \multicolumn{4}{|c|}{ Water absorption (\%) } \\
\hline & & \multicolumn{2}{|c|}{$2 \mathrm{hrs}}$. & \multicolumn{2}{|c|}{$24 \mathrm{hrs}}$. \\
\hline \multirow{3}{*}{700} & 10 & 64.24 & $(3.32)$ & 91.22 & $(2.56)$ \\
\hline & 12 & 44.27 & (3.09) & 69.12 & (5.24) \\
\hline & 14 & 40.71 & $(3.75)$ & 59.62 & (3.71) \\
\hline \multirow{3}{*}{600} & 10 & 92.50 & (7.38) & 127.48 & $(6.16)$ \\
\hline & 12 & 82.78 & $(5.95)$ & 108.58 & $(2.05)$ \\
\hline & 14 & 79.84 & $(5.23)$ & 96.95 & (3.45) \\
\hline \multirow{4}{*}{500} & 10 & 139.02 & $(5.71)$ & & 206.77 \\
\hline & & & & & $(10.71)$ \\
\hline & 12 & 119.20 & $(3.06)$ & 140.81 & $(3.93)$ \\
\hline & 14 & 113.26 & (7.59) & 138.29 & $(2.55)$ \\
\hline
\end{tabular}

Standard deviations shown in bracket. 


\subsection{Mechanical Properties}

Sample of EFB board of size $290 \times 50 \times 12 \mathrm{~mm}$ placed flat on the supports as the load applied using a universal testing machine. The results on the MOR obtained were compared with rubber wood. Table 3 presents MOR of the EFB composite board at density 700, 600 and $500 \mathrm{~kg} / \mathrm{m}^{3}$. The resistance to rupture increase with the increasing of board density and resin content. Board with $700 \mathrm{~kg} / \mathrm{m}^{3}$ with $14 \%$ resin possess the highest MOR at 22.91 $\mathrm{N} / \mathrm{mm}^{2}$ followed by the board made with a resin content of $12 \%$ at $18.97 \mathrm{~N} / \mathrm{mm}^{2}$ resin with the same density. Lower MOR attained by the boards with density $500 \mathrm{~kg} / \mathrm{m}^{3}$ with $10 \%$ resin content at $6.07 \mathrm{~N} / \mathrm{mm}^{2}$ followed by $12 \%$ at $6.37 \mathrm{~N} / \mathrm{mm}^{2}$ ) and $14 \%$ at $6.75 \mathrm{~N} / \mathrm{mm}^{2}$ resin content. The boards of $600 \mathrm{~kg} / \mathrm{m}^{3}$ gives an increasing trend from $10 \%$ at $10.2 \mathrm{~N} / \mathrm{mm}^{2}$ to $12 \%$ at $10.26 \mathrm{~N} / \mathrm{mm}^{2}$ and $14 \%$ at $12.77 \mathrm{~N} / \mathrm{mm}^{2}$ resin content. The EFB boards at density 700 $\mathrm{kg} / \mathrm{m}^{3}$ with 12 and $14 \%$ resin contents passed the minimum requirement for MOR at 14 $\mathrm{N} / \mathrm{mm}^{2}$ for general use's type according to the standard of EN 312-3 (European standard, 1996). Compared with a convenient board made from rubber wood (Paridah et al., 2010), the MOR value of EFB composite board $700 \mathrm{~kg} / \mathrm{m}^{3}$ with $14 \%$ had a quite identical property at 22.91 to $22.8 \mathrm{~N} / \mathrm{mm}^{2}$.

The MOE is related to the stiffness of the board, where the higher MOE meant the greater the stiffness. The boards tend to be brittle when the MOE is too high and tends to be ductile or flexible when the value is small (Wahab et al., 2016b; 2013; Rasat et al., 2011; Yang et al., 2003). MOE of EFB boards presented in Table 3. The highest value of MOE attained by the board at density $700 \mathrm{~kg} / \mathrm{m}^{3}$ with $14 \%$ resin content at $2059.56 \mathrm{~N} / \mathrm{mm}^{2}$ followed by $12 \%$ at $1683.93 \mathrm{~N} / \mathrm{mm}^{2}$ and $10 \%$ at $1063.43 \mathrm{~N} / \mathrm{mm}^{2}$ resin of the same density of the board. Boards at density $500 \mathrm{~kg} / \mathrm{m}^{3}$ with $10 \%$ at $385.64 \mathrm{~N} / \mathrm{mm}^{2}$ resin has low MOE followed by $12 \%$ at 419.43 $\mathrm{N} / \mathrm{mm}^{2}$ and $14 \%$ at $447.44 \mathrm{~N} / \mathrm{mm}^{2}$ resin of the same density. MOE value of the board 600 $\mathrm{kg} / \mathrm{m}^{3}$ is an increase from $10 \%$ at $673.82 \mathrm{~N} / \mathrm{mm}^{2}$ to $12 \%$ at $773.37 \mathrm{~N} / \mathrm{mm}^{2}$ and $14 \%$ at $1006.78 \mathrm{~N} / \mathrm{mm}^{2}$ resin content. The EFB boards at density $700 \mathrm{~kg} / \mathrm{m}^{3}$ with $14 \%$ resin content not only met the minimum requirement for MOE at $1800 \mathrm{~N} / \mathrm{mm}^{2}$ for general use's type of board according to the standard of EN 312-3 but exceeded the required values. The maximum MOE value of the EFB composite boards manufactured in this study at $2059.56 \mathrm{~N} / \mathrm{mm}^{2}$. This value is just slightly lower than the MOE of rubber wood at $2381 \mathrm{~N} / \mathrm{mm}^{2}$.

Table 3: MOR and MOE of EFB boards at different density and resin content.

\begin{tabular}{cccr}
\hline Board density $\left(\mathrm{kg} / \mathrm{m}^{3}\right)$ & Resin content $(\%)$ & MOR $\left(\mathrm{N} / \mathrm{mm}^{2}\right)$ & \multicolumn{1}{c}{ MOE $\left(\mathrm{N} / \mathrm{mm}^{2}\right)$} \\
\hline 700 & 10 & $11.03(3.33)$ & $1063.43(348.71)$ \\
& 12 & $18.97(3.09)$ & $1683.93(255.10)$ \\
& 14 & $22.91(3.81)$ & $2059.56(285.01)$ \\
\hline 600 & 10 & $10.20(0.79)$ & $673.82(55.64)$ \\
& 12 & $10.26(3.07)$ & $773.37(156.73)$ \\
& 14 & $12.77(3.37)$ & $1006.78(231.94)$ \\
\hline 500 & 10 & $6.07(1.54)$ & $385.64(108.02)$ \\
& 12 & $6.37(0.88)$ & $419.43(88.55)$ \\
& 14 & $6.75(1.47)$ & $447.44(134.29)$
\end{tabular}


*Paridah et al. (2010), and the standard deviations shown in bracket.

It was evident from Table 4 that the EFB composite boards $700 \mathrm{~kg} / \mathrm{m}^{3}$ with $14 \%$ resin content give the highest IB value at $0.98 \mathrm{~N} / \mathrm{mm}^{2}$ followed by $12 \%$ at $0.77 \mathrm{~N} / \mathrm{mm}^{2}$ resin of the same board density. The lowest value of IB was reported by the boards at $500 \mathrm{k} / \mathrm{gm}^{3}$ with $10 \%$ at $0.18 \mathrm{~N} / \mathrm{mm}^{2}$ followed by $12 \%$ at $0.19 \mathrm{~N} / \mathrm{mm}^{2}$ and $14 \%$ at $0.23 \mathrm{~N} / \mathrm{mm}^{2}$ resin content of the same board density. IB value of the panel $600 \mathrm{~kg} / \mathrm{m}^{3}$ increase from $10 \%$ at $0.28 \mathrm{~N} / \mathrm{mm}^{2}$ to $12 \%$ at $0.31 \mathrm{~N} / \mathrm{mm}^{2}$ and $14 \%$ at $0.36 \mathrm{~N} / \mathrm{mm}^{2}$ resin content. EFB composite boards $700 \mathrm{~kg} / \mathrm{m}^{3}$ with 10,12 and $14 \%$ resin contents were passed the minimum requirement value of the general type of board at $0.4 \mathrm{~N} / \mathrm{mm}^{2}$. The IB values obtained from the EFB composite boards were slightly lower than of rubber wood at $1.3 \mathrm{~N} / \mathrm{mm}^{2}$. The boards with low density possess low IB due to the existence of more voids in it. Poor boards preparation will lead to most of the inter-particle spaces remaining as voids. The voids directly caused inefficiency of the inter-fiber bonding (Ashori \& Nourbakhsh, 2008).

Internal bonding of UF resin composite board significantly improved with the increase in the platen temperature. The Higher temperature of the platen promotes higher cross-linking and curing of the resin. During pressing process, the temperature at a board's core is the lowest compared to the surface. Corrected platen temperature has to be applied to ensure that the core reaches a sufficiently high temperature to allow the resin to cure. Application of wax can result in lower internal bonding. The differences in chemical bonding between UF resin and particles and the wax interferes with the UF resin when hydrogen bonds formed (Papadopoulos, 2007).

Table 4: Internal bonding of EFB boards at different density and resin content.

\begin{tabular}{ccccc}
\hline $\begin{array}{c}\text { Board density } \\
\left(\mathrm{kg} / \mathrm{m}^{3}\right)\end{array}$ & $\begin{array}{c}\text { Resin content } \\
(\%)\end{array}$ & $\begin{array}{c}\text { Internal bonding } \\
\left(\mathrm{N} / \mathrm{mm}^{2}\right)\end{array}$ & $\begin{array}{c}\text { SWe } \\
\left(\mathrm{N} / \mathrm{mm}^{2}\right)\end{array}$ & $\begin{array}{c}\text { SWf } \\
\left(\mathrm{N} / \mathrm{mm}^{2}\right)\end{array}$ \\
\hline 700 & 10 & $0.54(0.06)$ & $412.27(38.10)$ & $459.72(42.45)$ \\
& 12 & $0.77(0.12)$ & $440.67(35.38)$ & $511.23(32.45)$ \\
& 14 & $0.98(0.08)$ & $467.47(46.18)$ & $512.37(87.26)$ \\
\hline 600 & 10 & $0.28(0.07)$ & $232.72(20.19)$ & $305.40(24.23)$ \\
& 12 & $0.31(0.08)$ & $239.08(25.01)$ & $314.60(34.51)$ \\
& 14 & $0.36(0.17)$ & $302.13(41.53)$ & $321.62(32.27)$ \\
\hline 500 & 10 & $0.18(0.04)$ & $168.18(23.56)$ & $193.42(29.58)$ \\
& 12 & $0.19(0.02)$ & $178.82(39.51)$ & $244.50(50.53)$ \\
& 14 & $0.23(0.03)$ & $189.93(20.05)$ & $268.38(48.04)$ \\
\hline EN 312-3 & & 0.40 & 360.0 & \\
Rubber wood & & $1.30^{*}$ & & \\
\hline
\end{tabular}

*Paridah et al. (2010), and the standard deviations shown in bracket. 


\section{MInstitute Macrothink $_{\text {Int }}$}

Table 4 showed the results of the edge screw withdrawal tests on EFB composite boards. The boards at density $700 \mathrm{k} / \mathrm{gm}^{3}$ with $14 \%$ resin gives the highest value at $467.47 \mathrm{~N} / \mathrm{mm}^{2}$, followed by $440.67 \mathrm{~N} / \mathrm{mm}^{2}$ with $12 \%$ and $412.27 \mathrm{~N} / \mathrm{mm}^{2}$ with $10 \%$ resin of the same density boards. The lowest value of edge screw withdrawal was given by the board at $500 \mathrm{~kg} / \mathrm{m}^{3}$ with $10 \%$ resin was $168.18 \mathrm{~N} / \mathrm{mm}^{2}$ content followed by $12 \%$ at $178.82 \mathrm{~N} / \mathrm{mm}^{2}$ and $14 \%$ resin at $189.93 \mathrm{~N} / \mathrm{mm}^{2}$ of the same boards' density. The edge screw withdrawal value for boards at $600 \mathrm{~kg} / \mathrm{m}^{3}$ increases from $10 \%$ at $232.72 \mathrm{~N} / \mathrm{mm}^{2}$ to $12 \%$ at $239.08 \mathrm{~N} / \mathrm{mm}^{2}$ and $14 \%$ resin at $302.13 \mathrm{~N} / \mathrm{mm}^{2}$. The EFB composite boards at $700 \mathrm{~kg} / \mathrm{m}^{3}$ with 10,12 and $14 \%$ resin met the minimum requirement for edge screw withdrawal according to BS 5669 (British standard, 1989). They exceeded the $360 \mathrm{~N} / \mathrm{mm}^{2}$ value that used as the standard.

The face screw withdrawal of the EFB composite boards are shown in Table 4. Boards of 700 $\mathrm{kg} / \mathrm{m}^{3}$ with $14 \%$ resin content gives the highest values in the screw withdrawal at 512.37 $\mathrm{N} / \mathrm{mm}^{2}$ followed by $12 \%$ at $511.23 \mathrm{~N} / \mathrm{mm}^{2}$ and $14 \%$ resin at $459.72 \mathrm{~N} / \mathrm{mm}^{2}$ of the same density boards. The lowest value was obtained by boards having a density of $500 \mathrm{~kg} / \mathrm{m}^{3}$ with $10 \%$ at $193.42 \mathrm{~N} / \mathrm{mm}^{2}$ resin content followed by $12 \%$ at $244.5 \mathrm{~N} / \mathrm{mm}^{2}$ and $14 \%$ resin at $268.38 \mathrm{~N} / \mathrm{mm}^{2}$ of the same density boards. Face screw withdrawal of the boards with 600 $\mathrm{kg} / \mathrm{m}^{3}$ increases from $10 \%$ resin at $305.4 \mathrm{~N} / \mathrm{mm}^{2}$ to $12 \%$ at $314.6 \mathrm{~N} / \mathrm{mm}^{2}$ and $14 \%$ resin at $321.62 \mathrm{~N} / \mathrm{mm}^{2}$. The higher particle loading was to strengthen the boards as well as increases their densities assists the boards to hold the screw better. The screw withdrawal resistance is highly associated with the board density and the particles' geometry (Wahab et al., 2008; 2016c; Wong et al., 1999).

\subsection{Microscopy Studies}

Samples microscopy for the study randomly selected from the EFB boards. Observations made on their structure especially the occurrence of the fibers compression, binder-fiber compatibility, and existence voids. The board's sample at a density of $500 \mathrm{~kg} / \mathrm{m}^{3}$ with UF resin content of $10 \%$ were taken for the micrographic studies as the boards have the lowest physical and strength properties). Figure 1 shows the micrographs of a cross-section of EFB composite board with resin content level $10 \%$ at 100x magnification. Figure 1 showed the occurrences of fibers compression in the EFB composite boards. The fibers compression occurred during the pressing stage at different applied pressure and temperatures. EFB fibers in the boards' profile were forced to shrink to a specified thickness resulting in the compressed structure of the fibers. This led to the reduction of lumen void spaces and thus, increase the density of the board produced. 


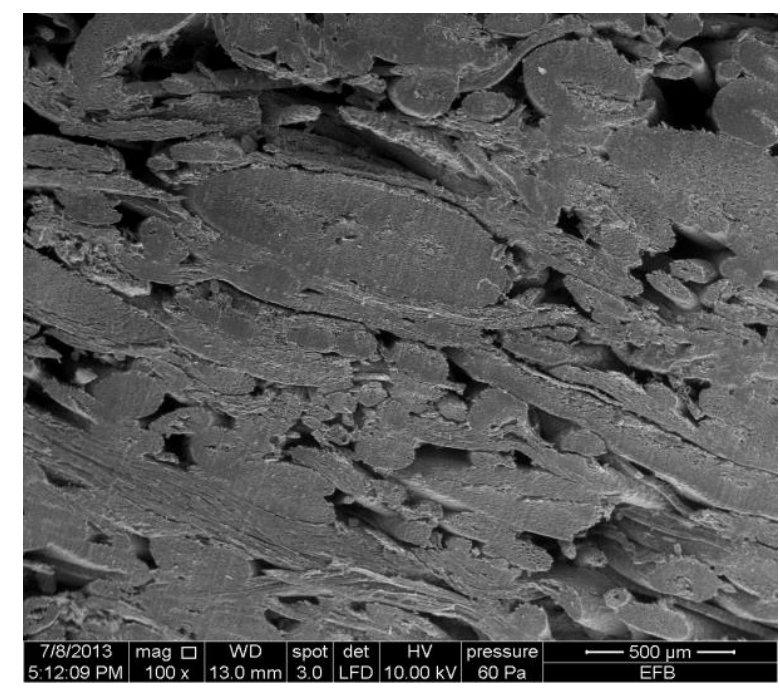

Figure 1. Micrographs of a cross section at density $500 \mathrm{k} / \mathrm{gm}^{3}$ EFB composite boards with resin $10 \%$ at $100 x$ magnification.

The fibers touch one to the others closely, and no UF resin observed clumped. This affects the result of the strength properties of the MOR and MOE properties of the board. As the load applied perpendicular to the EFB board surface, it creates compression stress on the top side on the board that transforms into tension stress at the bottom after exceeding the middle portion. The load stresses transferred from one particle to another particle, which, in this case, the EFB fiber's acts through a medium of the load transfer (Paridah et al., 2010). However, some voids do appear in the board's profile. The existence of voids in the EFB composite board profile reveals that there were empty spaces or gaps occurred at a particular area on the board. This possibly leads to the higher water absorption. The presence of voids created more surfaces of EFB fiber to be exposed to the surrounding humidity. The void's occurrence can be reduced by using or mixing smaller sizes of particles in the board manufacturing.

\subsection{Thermal Characteristics}

Figure 3 shows the TGA result for EFB composite boards. The decomposition in EFB composite boards begun at $100.46^{\circ} \mathrm{C}\left(1^{\text {st }}\right.$ peak $)$. It continued to the $2^{\text {nd }}$ peak at $204.81^{\circ} \mathrm{C}$ and completed at the $3^{\text {rd }}$ peak $\left(380.83^{\circ} \mathrm{C}\right)$. Figure 4 shows the degradation of UF resin initiated at $99.93^{\circ} \mathrm{C}\left(1^{\text {st }}\right.$ peak $), 168.45^{\circ} \mathrm{C}\left(2^{\text {nd }}\right.$ peak $)$ and completed at $389.26^{\circ} \mathrm{C}\left(3^{\text {rd }}\right.$ peak $)$. Table 5 represents TGA weight loss (\%) with temperature for UF resin boards. The loss of UF resin in weight was the highest at $3^{\text {rd }}$ peak at $58.48 \%$, followed by the $2^{\text {nd }}$ peak at $9.39 \%$ and the $1^{\text {st }}$ peak (8.43\%). The final decomposition of the EFB composite board is lower than of the UF resin at 389.26 to $380.83^{\circ} \mathrm{C}$ indicating the presence of cellulose fibers (from $\mathrm{EFB}$ ) significantly affecting the thermal stability of the composite boards. This probably due to the disturbance in the original crystal lattice of the composite by the EFB composite boards (Singha \& Thakur 2009). 


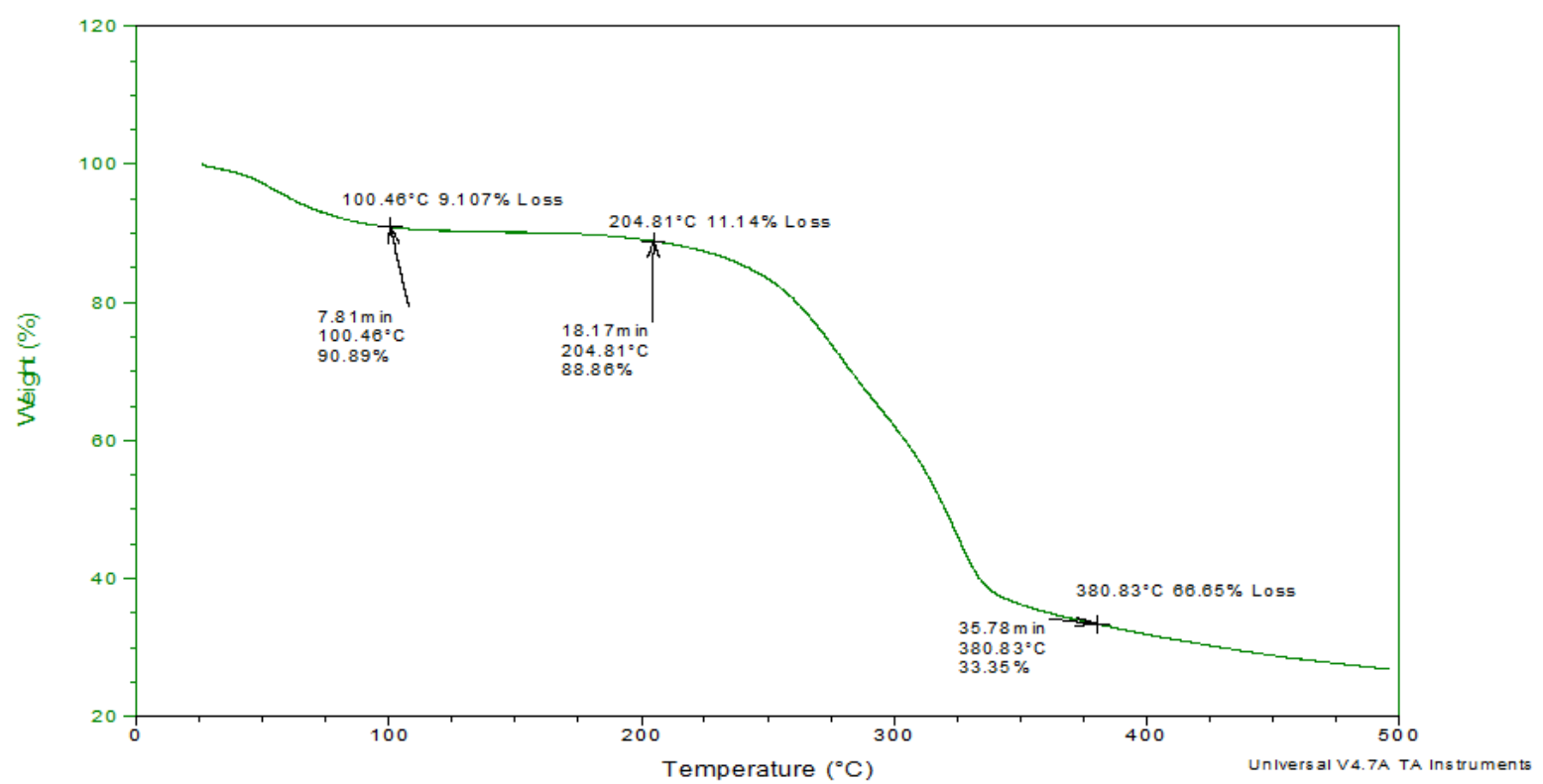

Figure 3. TGA properties of EFB composite boards.

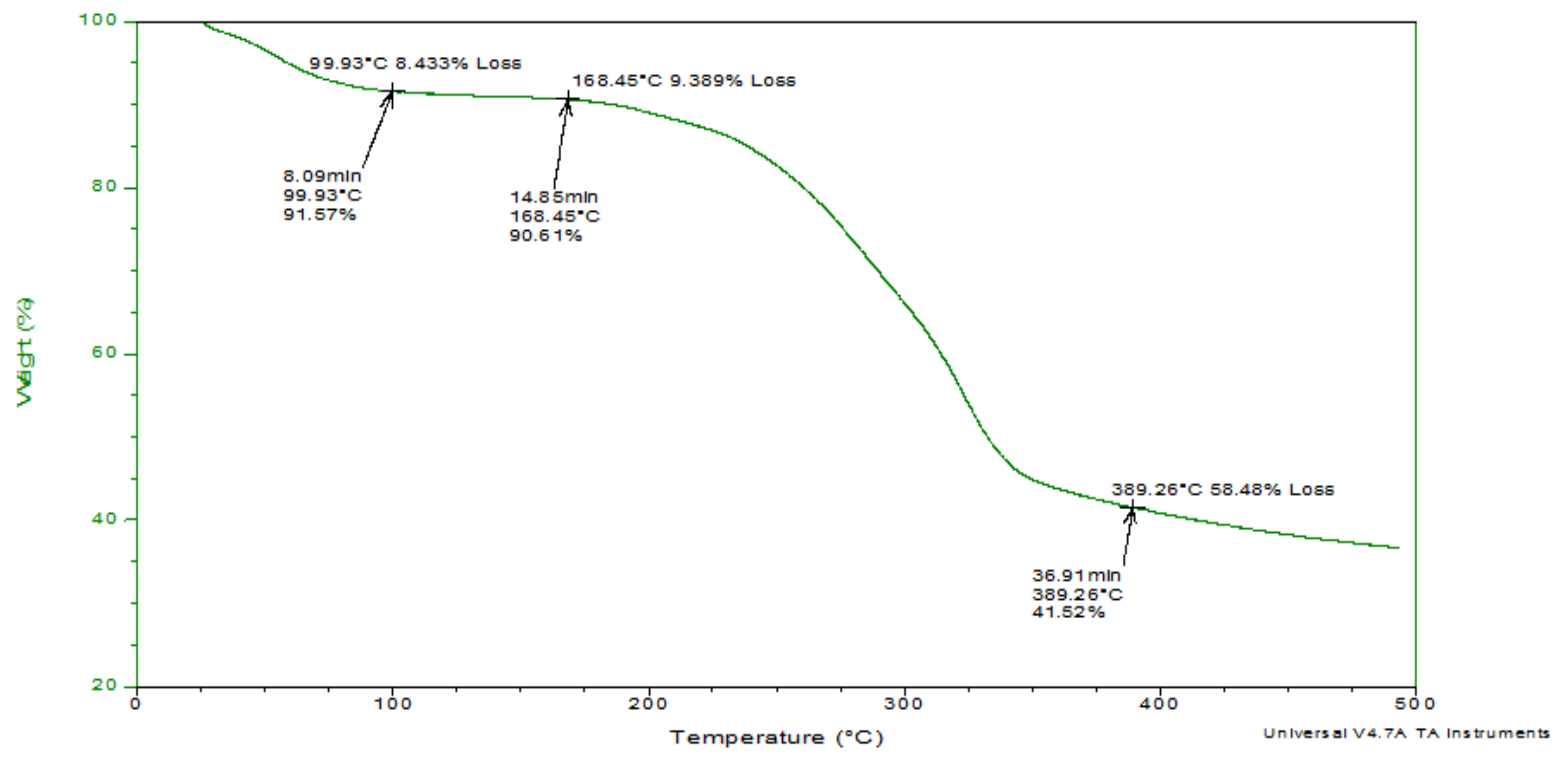

Figure 4. TGA properties of UF resin.

Table 5. TGA weight loss (\%) with temperature for EFB composite boards and UF resin.

\begin{tabular}{llccc}
\hline & & $1^{\text {st }}$ peak & $2^{\text {nd }}$ peak & $3^{\text {rd }}$ peak \\
\hline EFB composite boards & Temperature $\left({ }^{\circ} \mathrm{C}\right)$ & 100.46 & 204.81 & 380.83 \\
& Weight loss $(\%)$ & 9.12 & 11.14 & 66.65 \\
\hline UF resin boards & Temperature $\left({ }^{\circ} \mathrm{C}\right)$ & 99.93 & 168.45 & 389.26 \\
& Weight loss $(\%)$ & 8.43 & 9.39 & 58.48 \\
\hline
\end{tabular}

The degradation of the EFB boards and UF resin started by the depolymerization of 
molecular structure and the dehydration (loss of water). The free formaldehyde in UF resin slowly released (Zorba et al., 2008). The process continued by the cleave of linkages that occurred in the composite and UF resin. Carbon-hydrogen $(\mathrm{C}-\mathrm{H})$ bonds broken first, followed by carbon-oxygen $(\mathrm{C}-\mathrm{O})$ bonds, carbon-carbon $(\mathrm{C}-\mathrm{C})$ bonds, and hydrogen-oxygen $(\mathrm{O}-\mathrm{H})$ bonds. The energy needed to break those linkages were $414 \mathrm{~kJ} / \mathrm{mol}$ for $-\mathrm{C}-\mathrm{H}$ bond, 356 $\mathrm{kJ} / \mathrm{mol}$ for $-\mathrm{C}-\mathrm{O}$ bond and $347 \mathrm{~kJ} / \mathrm{mol}$ for $-\mathrm{C}-\mathrm{C}$ and last but not least the $\mathrm{O}-\mathrm{H}$ bond, 460 $\mathrm{kJ} / \mathrm{mol}$. This is the stage where cellulose, hemicellulose, and lignin began to decompose. The thermal degradation of polymer blocks of biomass occurred at the second peak. Hemicellulose and Lignin degraded earlier (Soom et al., 2006; Abdullah \& Bridgwater, 2006). This is due to their molecular structure that less rigid (amorphous than cellulose) compared to cellulose. The introduction of oxygen $\left(3^{\text {rd }}\right.$ peak) causes combustion to occur, and the final weight loss infers the amount of carbon in the composite. The carbon contents of the boards recorded at $58.48 \%$ for UF resin and $66.65 \%$ for EFB composite boards (see Table 5).

\section{Conclusion}

The EFB eco-composite boards' properties met all requirements for commercial application. The boards' density and resin content applied influenced on the board's overall properties. The studies indicated an increase across the board physical and mechanical properties. The highest MOR and MOE value achieved in this study were at $22.91 \mathrm{~N} / \mathrm{mm}^{2}$ and 2059.56 $\mathrm{N} / \mathrm{mm}^{2}$. The maximum value for internal bonding was at $0.98 \mathrm{~N} / \mathrm{mm}^{2}$. The edge and face screw withdrawal at $467.47 \mathrm{~N} / \mathrm{mm}^{2}$ and $512.37 \mathrm{~N} / \mathrm{mm}^{2}$ respectively.

The boards produced at density $700 \mathrm{~kg} / \mathrm{m}^{3}$ with $14 \%$ resin showed an excellent overall property with good dimensional stability. The boards are unlikely to swell with less porous structure when exposed to the wet environment.

Composite boards at $500 \mathrm{~kg} / \mathrm{m}^{3}$ density with $10 \%$ resin has low properties both in the physical and mechanical. The boars shows numerous voids structure that absorbs and traps moisture. Inter particle's bonding thus diminished as moisture interrupts, causing low board performance.

The UF resin showed higher thermal stability compared to regular boards when analyzed under TGA. Thermogravimetric analysis conducted to study the thermal stability of the boards manufactured. The UF resin boards were slightly more stable than of the normal composite boards.

\section{References}

Abdullah, N., \& Bridgwater, A. V. (2006). Pyrolysis liquid derived from oil palm empty fruit bunches. Journal of Physical Science, 17(2), 117-129.

Ashori, A., \& Nourbakhsh, A. (2008). Effect of press cycle time and resin content on physical and mechanical properties of particleboard panels made from the under utilized low-quality raw materials. Industrial crops and products, 28(2), 225-230.

https://doi.org/10.1016/j.indcrop.2008.02.015

British Standard BS 5669. (1989). Particleboard: Methods of sampling, conditioning, and test. 
British Standards Institution.

European standard EN 310. (1993d). Wood-based panels: Determination of the modulus of elasticity in bending and of bending strength. European Committee for Standardisation, Brussels, Belgium.

European standard EN 312-3. (1996). Particleboards-Specifications-Part 3: Requirements for boards for interior fitments (including furniture) for use in dry conditions. European Standardization Committee, Brussels.

European standard EN 317. (1993c). Particleboard and Fiberboards; Determination of swelling in thickness after immersion in water. European Committee for Standardisation, Brussels, Belgium.

European standard EN 322. (1993a). Wood-based panels: Determination of moisture content. European Committee for Standardisation, Brussels, Belgium.

European standard EN 323. (1993b). Wood-based panels: Determination of density. European Committee for Standardization, Brussels, Belgium.

European standard EN 325. (2012). Wood-based panels: Determination of dimensions of test pieces. European Committee for Standardization, Brussels- Belgium.

Garay, R. M., MacDonald, F., ..., \& Araya, J. E. (2009). Particleboard made with crop residues mixed with wood from Pinus radiata. BioResources, 4(4), 1396-1408.

Guler, C., \& Büyüksarı, Ü. (2011). Effect of production parameters on the physical and mechanical properties of particleboards made from the peanut (Arachis hypogaea L.) hull. BioResources, 6(4), 5027-5036.

Khalid, I., Sulaiman, O., ..., \& Rasat, M. S. M. (2015). Evaluation of layering effects and adhesive rates of laminated compressed composite panels made from oil palm (Elaeis guineensis) fronds. Materials \& Design, 68, 24-28.

https://doi.org/10.1016/j.matdes.2014.12.007

Khalil, H. S. A., Alwani, M. S., \& Omar, A. K. M. (2007). Chemical composition, anatomy, lignin distribution, and cell wall structure of Malaysian plant waste fibers. BioResources, 1(2), 220-232.

Loh, Y. W., H'ng, P. S., ..., \& Tan, C. K. (2010). Properties of particleboard produced from the admixture of rubberwood and mahang species.Asian Journal of Applied Sciences, 3(5), 310-316. https://doi.org/10.3923/ajaps.2010.310.316

Papadopoulos, A. (2007). Property comparisons and bonding efficiency of UF and PMDI bonded particleboards as affected by key process variables.BioResources, 1(2), 201-208.

Paridah, M. T., Saifulazry, S. O. A., ..., \& Rahim, S. (2010). Mechanical and physical properties of particleboard made from 4-yea-old rubberwood of RRIM 200 series clones. Journal of Tropcal Forest Sciences. 22(4), 440-447. 
Rasat, M. S. M., M. R., ..., \& Sitti Fatimah, M.R. (2013e). Properties of bio-composite lumbers from lignocelluloses of oil palm fronds Agricultural residues. International Journal on Advanced Science Engineering Information Technology, 3(3), 9-19. ISSN 2088-5334.

Rasat, M. S. M., Razak, W., ..., \& Siti Aoshah, N. N. (2013d). Compressed oil palm fronds composite: A preliminary study on mechanical properties. International Journal of Science, 2 (3). 31-41. ISSN 2305-3925.

Rasat, M. S. M., Wahab, R., ..., \& Khalid, I. (2011). Properties of composite boards from oil palm frond agricultural waste. BioResources, 6(4), 4389-4403.

Rasat, M. S. M., Wahab, R., ...., \& Ramle, S. F. M. (2013b). Strength Properties of Bio-composite Lumbers from Lignocelluloses of Oil Palm Fronds Agricultural Residues. International Journal on Advanced Science, Engineering and Information Technology, 3(3), 09-19.

Rasat, M. S. M., Wahab, R., ..., \& Yusoff, M. (2013c). Physical and mechanical properties Of Bio-Composite board from compressed Oil Palm Fronds. Advances in Natural and Applied Sciences, 7(5), 572-582.

Rasat, M. S. M., Wahab, R., ..., M., \& Kari, Z. A. (2013a). Effect of wood-fiber geometry size on mechanical properties of wood-fiber from Neolamarckia Cadamba species reinforced polypropylene composites. Journal of Tropical Resources and Sustainable Sciences, 1(1), 42-50.

Singha, A. S., \& Thakur, V. K. (2009). Study of mechanical properties of urea-formaldehyde thermosets reinforced by pine needle powder. BioResources,4(1), 292-308.

Soom, R. M., Wan Hasamudin, W. H., Top, A. M., \& Hassan, K. (2006). Thermal properties of oil palm fiber, cellulose and its derivatives. Journal of Oil Palm Research, 18 (December), 272-277.

Wahab, R., Abdus Salam, M., ..., \& Samsi, H.S. (2013). Properties of engineered oil palm composite boards from 32 year-old tree stems. ARPN Journal of Agricultural and Biological Science, 8(7): 541-545. ISSN 1990-6145.

Wahab, R., Khalid, I., ..., \& Mohd Fikri, A. (2016a). Physical, Mechanical and Thermal Properties of Bio-Composites Mixture of Gigantochloa Scortechinii and Themeda Arguens (L.) Hack at Different Ratios and Resin Contents. Research Journal of Pharmaceutical, Biological and Chemical Sciences 7 (4): 644-655. ISSN: 0975-8585.

Wahab, R., Mohamed, M., ..., \& Yusof, M. (2016c). Properties of Biocomposite Mixture of Oil Palm Frond and Kenaf Bast Fibers. Research Journal of Pharmaceutical, Biological and Chemical Sciences 7 (3), 986-994. ISSN: 0975-8585.

Wahab, R., Mustafa, M. T., ..., \& Yusof, M. (2016b). Physical, Mechanical and Morphological Studies on Bio-composite Mixture of Oil Palm Frond and Kenaf Bast Fibers. Journal of Plant Sciences, 11(1-3), 22-30. ISSN: 1816-4951, Academic Journals Inc. USA. https://doi.org/10.3923/jps.2016.22.30 


\section{Macrothink}

Journal of Agricultural Studies

ISSN 2166-0379

2017, Vol. 5, No. 3

Wahab, R., Samsi, H. W., ..., \& Salim, R. (2008). Properties of Laminated veneer lumber from oil palm trunks. Journal of Plant Sciences, 3(4), 255-259.

https://doi.org/10.3923/jps.2008.255.259

Wong, E. D., Zhang, M., Wang, Q., \& Kawai, S. (1999). Formation of the density profile and its effects on the properties of particleboard. Wood Science and Technology, 33(4), 327-340.

https://doi.org/10.1007/s002260050119

Yang, H. S., Kim, D. J., \& Kim, H. J. (2003). Rice straw-wood particle composite for sound absorbing wooden construction materials. Bioresource Technology, 86(2), 117-121.

https://doi.org/10.1016/S0960-8524(02)00163-3

Zheng, L., Pan, Z., ..., \& Blunk, S. (2005). Medium-density particleboard from saline Jose tall wheatgrass. Proceedings from '05 ASAE Annual International Meeting. Florida.

https://doi.org/10.13031/2013.19578

Zorba, T., Papadopoulou, E., ..., \& Chrissafis, K. (2008). Urea-formaldehyde resins characterized by thermal analysis and FTIR method. Journal of Thermal Analysis and Calorimetry, 92(1), 29-33. https://doi.org/10.1007/s10973-007-8731-2

\section{Copyright Disclaimer}

Copyright for this article is retained by the author(s), with first publication rights granted to the journal.

This is an open-access article distributed under the terms and conditions of the Creative Commons Attribution license (http://creativecommons.org/licenses/by/4.0/). 